International Journal of Social Science and Economic Research

ISSN: 2455-8834

Volume: 05, Issue: 04 "April 2020"

\title{
THE INCONSPICUOUS FUTURE OF THE EU - MERCOSUR FREE TRADE AGREEMENT
}

\author{
Rahul Kamath \\ Pursuing Master of Arts in International Studies, Symbiosis \\ School of International Studies, Pune.
}

DOI: 10.46609/IJSSER.2020.v05i04.004 URL: https://doi.org/10.46609/IJSSER.2020.v05i04.004

\begin{abstract}
The twenty-first century world trade mainly revolves around the protectionist environment driven by the United States of America and China. In reaction to such protectionism, the European Union - MERCOSUR Free Trade Agreement is a reaction towards protectionism. This agreement took twenty years in the making when the deadlock was first resolved in 2016. This new FTA will be one of the most significant and most sophisticated trade areas in the world. Primarily, because of the magnitude of the trade and investment flows. Together Mercosur and the EU account for a GDP of US\$ 20 trillion. Secondly, it is a combined market of 780 million people, almost 1/10th of the total population. Even before the trade agreement, the EU was Mercosur's second-biggest trading partner and the largest foreign investor in the region. The relationship between the EU and Mercosur is unique as it is EU 8th largest non - regional partner, especially when the EU does not have a preferential trade agreement in Latin America. The new free trade agreement has generated expectations on both sides of Atlantic. The agreement will increase the trade flows, create jobs and decrease youth unemployment, freeing tariffs and fostering markets access to both the EU and Mercosur but environmental activists, indigenous rights campaigners, European Beef farmers and small - scale farmers have denounced the trade agreement deal. The creation of such an agreement between two big regional blocs minimizes losses and stimulate sectors to reach its efficiency. This paper aims to identify the challenges and lay a roadmap for the future of the EU - MERCOSUR trade with the current political system in both the blocs. The agreement is in its principle stages and has not been ratified yet, but it is an agreement worth fighting for as it has the potential for development towards higher growth.
\end{abstract}

Keywords: European Union, MERCOSUR, Free Trade Agreement, Protectionism, WTO

INTRODUCTION 
International Journal of Social Science and Economic Research

ISSN: $2455-8834$

Volume: 05, Issue: 04 "April 2020"

The European Union - Mercosur free trade agreement (FTA) is an iconic trade agreement between two inter-regional blocs. The trade agreement was reached in principle in 2019 at the G20 Osaka summit after nearly twenty years of negotiations. This trade agreement is essential because once ratified; it will become the largest FTA in terms of population. The combined market of $29 \mathrm{EU}$ states and four Mercosur members roughly adds up to 780 million. That is roughly $1 / 10^{\text {th }}$ of the global population. Also, the combined GDP of the EU - Mercosur is around US\$ 20 trillion, which would make it the largest economy in the world. Both the EU and Mercosur are a customs union, and before 2019, no FTA has ever been signed between two custom unions. Under this new FTA, Mercosur will remove tariffs on 90 per cent of industrial goods import from the EU whereas the EU will remove tariffs on 100 per cent of its imports from Mercosur. The EU will also remove tariffs on 82 per cent of agricultural goods while Mercosur will remove tariffs on 93 per cent with 7 per cent allotted to preferential trade. While all of it sounds ideal and envisions a brighter future for both the blocs, then one can wonder why it took over twenty years in the making.

The talks between EU - Mercosur began in 1999 but kept stalling due to objection from European beef producers and small- scale European farmers while governments across South America preferred south-south cooperation than cooperating with their erstwhile European colonies. Similarly, European interests deferred, and they sought their priorities elsewhere. It was only in 2016 that both the blocs decided to renegotiate amidst protectionist policies around the world. The EU hoped that the trade agreement could bring a significant break in this renewal of trade protectionism. Before 2016, the EU, along with its predecessor the European Economic Community had signed a series of bilateral agreements with four countries of Mercosur (Argentina, Brazil, Paraguay and Uruguay). In 1995, the Framework Cooperation Agreement was signed between the EU and Mercosur which aimed at an interregional association linking the two blocs in a political, social, economic and cultural relationship. The motive of this framework was to reach a definitive agreement on free trade.

The paper aims to examine the importance of the EU - Mercosur FTA, challenges for this trade agreement, the ratification process, the need for complementary reforms and finally concluding with the political whirlwind in order to structure this interregional FTA in such a way that it is a win-win scenario for two regional blocs separated by the Atlantic Ocean.

\section{IMPORTANCE OF THE EU- MERCOSUR FREE TRADE AGREEMENT}

The FTA between the two blocs even though has been signed in 2019, it has been agreed only as a principle. No final texts have been prepared, and it is yet to be ratified by the member states of EU - Mercosur. Once, ratified, the trade agreement is phased over fifteen years which makes its implementation imperceptible. Nonetheless, the time frame given could counter the various 
challenges involved in the agreement. The EU - Mercosur trade deal is a growing response to protectionism that we see in the $21^{\text {st }}$ century. The Mercosur economies are struggling due to internal corruption and domestic unrests. The governments are reformists in the wake of economic crises with Argentina needing an IMF bailout package in 2015 and Brazil struggling to curb its income inequality. The trend of income inequality in the Mercosur states is one of the primary reasons why such a trade agreement can help boost their middle class and increase their savings and purchasing power parity whereas, for the EU, this trade agreement can help counter new protectionists threats. Even though the trade agreement is its conceivable stage, the agreement is equally important to both the regional blocs in four ways.

Firstly, Argentina and Brazil, account for over 90 per cent of Mercosur's GDP, which is also the world's twenty - fourth and tenth-largest economies respectively. In terms of geography as well, the two countries amass over $90 \%$ of Mercosur's landmass. The two economies primarily survive on resources and agriculture. The region as such is hugely resourceful, and agriculture and livestock are the backbones of the Latin American economy, but their primary reason for economic crisis has been an inability to find an apt market for their products. By signing the FTA with the EU, which is the world's largest and most diverse source of industrial goods and a market to over 300 million people, the Mercosur nations accept the reality of pushing for FTA of this grand stature. The EU is a global and a multicultural market with vast size, opportunities and equally high competition. The competition in the EU is incomparable as there is always a demand for the best products, and the market is such that nothing is acceptable apart from the best. This one aspect could bring in stricter discipline within Mercosur nations. The FTA will not only increase the demand for Mercosur goods in Europe but also open markets in the Mercosur region, especially in the hardcore industries such as automobile, innovation and service sector.

Table 1: EU - Mercosur Trade Relations from 1998 - 2018 in US\$ Billions

$\begin{array}{llll}\text { EU EXPORTS TO MERCOSUR } & 1998 & 2008 & 2018\end{array}$

\begin{tabular}{lccc}
\hline Agricultural, Forestry \& Fishery & 0.2 & 0.2 & 0.5 \\
\hline Minerals & 0.1 & 1.7 & 3.5 \\
\hline Manufacturing sector & 25.9 & 44.6 & 44.7 \\
\hline Total exports & 26.1 & 46.5 & 48.6
\end{tabular}


International Journal of Social Science and Economic Research

ISSN: $2455-8834$

Volume: 05, Issue: 04 "April 2020"

\section{MERCOSUR EXPORTS TO EU}

Agricultural, Forestry \& Fishery

Minerals

Manufacturing sector

Total exports
1998

5.3

1.9

11.9

19.1
2008

16

12.9

44.2

73.1

Source: UN Comtrade data.

Secondly, the agreement as reiterated is a response to trade protectionism practiced across the world by nationalist governments. Amidst the US-China trade war, several other economies and markets have been benefitting. The demand for Brazilian soybeans, pork and other livestock products have seen upward growth since 2016. Furthermore, the EU is one of the largest consumers of red meat, can be the beneficiary of such a trade agreement. The agreement consolidates the EU's position as the bloc best able to function in such a rule-based trading system.

Thirdly, the Mercosur agriculture is the world's most competitive agricultural producers. The FTA will not only open European markets for Mercosur goods such as beef, poultry, sugar and ethanol but also be useful for Brazilian juice exporters and Argentine fisheries. The deal eliminates 93 per cent of tariffs on the EU exports which is a win-win situation for both the blocs as European industries such as automobile, heavy industries and textile have improved access to the Mercosur market and a total of $€ 4.5$ Billion worth of duties will be saved by the EU and US\$ 1.6 billion by the Mercosur. Finally, even though no final texts have been prepared, it is understood that the agreement is beyond reducing tariffs and quotas. The agreement includes increased access to public procurement contracts and protection for regional food. The legal team will be placing and protecting 357 European eateries and beverages from imitation including the Italian dry-cured ham known as Prosciutto di Parma and the Belgian cheese Fromage de Herve. Apart from legal guarantees, custom procedures will also be simplified.

\section{CHALLENGES FOR THE EU - MERCOSUR FREE TRADE AGREEMENT}

The first significant challenge the agreement faces is that of ratification, which will be discussed later in the paper as a separate sub-section. The challenges are equally significant for both yet different. The reason the whole agreement took twenty years in the making is because of backlashes from European beef producers and small-scale farmers. Europe is one of the largest consumers of red meat and for so long they have been successful in producing their meat in their backyard, but the trade agreement imports beef from Brazil, the world's largest producer of Beef, 


\section{International Journal of Social Science and Economic Research}

ISSN: $2455-8834$

Volume: 05, Issue: 04 "April 2020"

at cheaper rates due to which there is a more enormous influx of Brazilian livestock in Europe. Under the agreement, up to 99,000 tons of Brazilian beef will be exported to the EU per year at a preferential rate of $7.5 \%$ tariffs. The European beef producers feel threatened by such agreement as it could put them out of business within five years. So is the case with small-scale farmers of Europe. Argentina and Brazil are extremely fertile region producing resource at a large scale, and the agreement will also flood the European markets with cheaper agricultural products which threaten to derail the small-scale economies. France and Poland have objected to influx of Mercosur agricultural goods into Europe due to this reason.

There is a significant concern among people regarding Brazil and the Amazon rainforest. The Amazon rainforest is the world's largest carbon sinks, but the amount of carbon the Amazon is absorbing is decreasing each year, primarily, due to deforestation. Brazil is one of the signatories to the Paris Climate Agreement, but since the election of President Jair Bolsonaro, Brazil has threatened to pull out of the agreement and deforestation in Amazon has reached its highest rate of all time with 13 per cent increase in deforestation. The primary reason for deforestation is cattle farming and is responsible for over 80 per cent of total deforestation. A clear negative correlation is seen in this area where increased Amazon deforestation has led to record beef exports from Brazil. Development at the expense of the environment is not development but progression as face value and regression as the real one.

The loggers, miners, farmers have all been illegally encroaching the land due to which the rate of deforestation is at an all-time high. The primary fear is that this agreement could further lead to an increase in deforestation due to increase in demand chain of agricultural and livestock products. This increase of deforestation results in destroying one of the largest carbon sinks in the world, which is entirely against the Paris Climate Accord of 2015. Furthermore, since President Bolsonaro's reign, the environment ministry has been weakened. He has encouraged mining and farming in the region which has not only resulted in massive deforestation but also threatened the lives of indigenous people living in the rainforest.

The Amazon is home to some of the largest indigenous communities, and due to deforestation, their lands are being usurped in the name of development. In 2019, over 20,000 gold miners illegally encroached the Yanomami Indigenous Territory, one of the largest indigenous tribes with over 23,000 people as of 2016. Besides this, President Bolsonaro has slashed the budget of Fundacao Nacional do Indio (FUNAI), a Brazilian governmental agency working to protect the Indigenous population. He has threatened to further encroach their lands and even remove the demarcation of the indigenous territories as feels their territories are an obstacle to national development. The threat to indigenous communities should be abolished in order to achieve fairness in the EU - Mercosur trade agreement. 


\section{International Journal of Social Science and Economic Research}

ISSN: $2455-8834$

Volume: 05, Issue: 04 "April 2020"

The other challenges that Mercosur members face is their economies. The members will have to put in place economic reforms to strengthen their competitiveness, and this can happen only when there is a rise in the middle class. Currently, the whole region faces severe income inequality. The Mercosur economy is polarity by all means; either one is all rich or all poor. There is no stable middle class. Having a stronger middle class can lead to competitive spirits which helps in facing the increased presence of world-class goods on their domestic markets. For the agreement to prosper, Mercosur members will eventually have to look outside the agricultural sectors as their principal export to the EU.

\section{THE RATIFICATION PROCESS}

The final texts of the trade agreement have not been finalized but once finalized it will be submitted to the Council of the European Union. It will then be decided whether it requires a mixed agreement, requiring national ratification or an EU - only agreement, requiring ratification by the Council and the European Parliament. It is suggested that most likely such an agreement would require ratification by members states after the approval by their national governments. The opposition to the EU - Mercosur agreement in Europe is based on four main concerns: economic damage to beef producing and agriculture industries in the EU, the policies of Bolsonaro government in Brazil, change of leadership in Argentina (return to Peronism) and impact of the trade agreement on deforestation in the Amazon. The four concerns have been discussed as a part of the challenges for the EU - Mercosur agreement.

The farmers in France, Poland, Ireland and Belgium have argued that reduction of tariffs and extension of quotas for agricultural products threatens their business extensively. Besides this, the EU farmers feel they are at a disadvantage because Mercosur farmers face lower environmental and labor protection standards. European farmers also feel that such an agreement could incentivize deforestation in the Amazon with façade of development, especially when Cattle farming, soybean and sugarcane farming requires vast acres of lands. On the social front, Brazil has been accused of violating human rights, and the EU as the torchbearer of protector of human rights can use the agreement as a political tool to improve the condition of weaker classes in the Mercosur region. In 2019, Dail Eireann, the lower house of Irish Parliament, rejected the trade deal and the Austrian parliament unanimously rejected the draft FTA as they expressed their concerns over Brazil's treatment of the Amazon wildfires. Stemming from the environmental concerns, the rise of Greens and European Free Alliance parties in the European Union and Parliament can also hinder the growth of the EU - Mercosur FTA as the Greens won 74 seats in the European Parliamentary elections. While the final document is being prepared, the EU should lay emphasis on political agreements with Mercosur to encourage and improve the social and human rights protection and lay emphasis on protecting the indigenous lands of the Amazon rainforest. 
International Journal of Social Science and Economic Research

ISSN: $2455-8834$

Volume: 05, Issue: 04 "April 2020"

\section{COMPLEMENTARY REFORMS}

To reap full rewards from the EU - Mercosur agreements, significant reforms are essential and needed. The agriculture sectors on both the blocs need reforms as the EU's labor force is declining due to ageing population and stronger immigration policies, younger workers from Mercosur region stand a higher chance and more significant opportunity in venturing in sectors besides agriculture. Economic reforms are needed in Brazil and Argentina as Brazil wrapped itself in massive corruption scandals, and the Macri government continued to struggle economically which eventually led to his demise as the President of Argentina. Macri was a strong supporter of EU - Mercosur deal. He pushed for such an interregional trade agreement, but President-elect Alberto Fernandez from Justicialist Party with Peronist policies at the helm, the role of Argentina in this agreement seems to be precarious.

The manufacturing sector of both the blocs are miles apart, and this is a severe challenge to Mercosur members. They face direct competition from European nations that are ranked in the top 10 whereas Brazil is ranked at 72 and Argentina at 81 in the World Economic Forum's competitiveness ranking. The ease of doing business in European countries is easier when compared to Mercosur members. If Mercosur members wish to reap full benefits from this trade deal, then the spirit of competitiveness and ease of doing business should increase, and this can happen only with by erasing the corruption scandals and by decreasing the government debt. Even though Argentina and Brazil have received a respectable amount of Foreign Direct Investments (FDIs) in recent years that has nowhere reduced the income disparity in the region. A large portion of population is relapsing into poverty (Estrades, 2012). The Mercosur members need first-generation remedies and reforms to improve their macroeconomics, reduction in public spending and increased investment in infrastructure. The increase in infrastructural and other structural reforms such as quality of public services, high - quality education, improving allaround governance and regulation in Mercosur would improve its competitiveness.

\section{THE POLITICAL WHIRLWIND}

Politics on both sides of the Atlantic is changing rapidly. Several countries in the region are protesting their governments, and there is increased dissatisfaction in both the continents. With Europe Union still waiting for Brexit, the continent of Latin America is experiencing a continental concern. South American countries like Chile, Haiti, Venezuela (former member of the Mercosur; suspended in 2016) and Bolivia are protesting their governments due to rise in the cost of living and increased public expenditure and income inequality which is a significant concern for the entire continent. The worries are that such protests and unrests can spill over the borders and creep into the Mercosur members. The political unrest in the region has the potential 


\section{International Journal of Social Science and Economic Research}

ISSN: $2455-8834$

Volume: 05, Issue: 04 "April 2020"

to lead a revolution against oppressive and corrupt regimes across the region, just like the $20^{\text {th }}$ century when Latin American countries fought against the military to become a democracy.

The politics behind the EU - Mercosur FTA is changing dynamically. The primary reason being Argentina, greatest obstacle to EU - Mercosur deal. When the deal was signed in principle, President Macri was a strong advocate of the deal, but his congress remained unconvinced and thought the benefits of the trade deal would be only for agribusiness elites and not other industries. President Macri, who sought to repair the fractured Argentine economy by slashing public spending and decreasing government debts and cut subsidies to the utility and transportation industries.

Macri's policies, which came to be known as gradualism, was supposed to instill confidence in Argentine economy and its people but things faltered, and Argentina borrowed its twenty-second International Monetary Fund (IMF) bailout package of US\$ 57 Billion. The argentine economy slipped into recession and inflation soared to fifty-five per cent, and over three million people slipped into poverty overnight. The borrowed funds from IMF has never benefited Argentina due to stricter austerity measures and wide range of conditionalities. The fund's assistance was perceived as humiliation and with that Macri's hopes of reelection faded. Macri's marketfriendly and foreign policy-oriented reforms did not manage to overhaul the economy. In the Argentine General elections held in October, Emanuel Macri lost to Alberto Fernandez from the Justicialist Party. The party is a left-wing party with Peronists approach towards governance. Peronists have counted industrial workers as their ardent supporters, and President-elect Alberto Fernandez has explicitly denounced and rejected the EU - Mercosur trade deal citing that such a deal would expose the domestic industry to the formidable competition from the European counterparts. Cristina Kirchner, former President of Argentina, is now the vice - president to Alberto Fernandez, believed in economic nationalism and autarky. It was this pre-calculated fear of a Peronist comeback that motivated the EU and Mercosur officials to speed up the negotiations. The outcome of a new Peronist presidency in Argentina is yet to be seen but the only hope to repair the Argentine economy and EU - Mercosur agreement lies in the hands of the Alberto Fernandez.

Brazil, on the other hand, is led by President Jair Bolsonaro. His presidency is surrounded by corruption scandals, and Brazil is bearing the costs of that corruption. His popularity in Brazil is steadily declining with over 36 per cent considering his tenure as awful. His inability to resolve the economic crisis has led to unrests amongst people. He cut $30 \%$ of education budget which was protested by the students in Rio de Janeiro and his lack of attention towards the Amazon forest fires have contributed to his low popularity in the international community. The EU Mercosur trade agreement fully commits to the Paris Climate Agreement, but Bolsonaro's threat of pulling out of the Climate agreement does not resonate well with his European counterparts. 


\section{International Journal of Social Science and Economic Research}

ISSN: $2455-8834$

Volume: 05, Issue: 04 "April 2020"

Brazil's questionable environmental policies could completely derail the trade agreement, and Bolsonaro's stance on environment is increasingly under scrutiny in Brussels.

Despite the presence of other Paraguay and Uruguay, the future of the EU - Mercosur free trade agreement predominantly lies in the hands of Buenos Aires and Brasilia because geographically and politically they dominate the region. Argentina and Brazil are Mercosur's largest economies and two most important trading partners, but their current state of economy and governance is rupturing and faltering at an unparalleled rate where the poverty rates are increasing in both the countries and income disparity is increasing. Internalizing on their governance and structure and then opening their markets would be beneficial for them, but their challenge lies in their ability and willingness to overcome such economic hauls together. The relationship between Brazil and Argentina has encompassed every possible dimension, and their relationship of enmity to friendship to alliances has spanned over two centuries. Today, their relationship is at its highest point.

\section{CONCLUSION}

The EU - Mercosur FTA is an agreement worth fight for considering its quantifiable gains. The gains if accompanied by well-structured domestic reforms, can represent a shift in international trading pattern especially between two regional blocs. The success of the EU - Mercosur FTA might give an impetus to Mercosur for achieving trade agreements with Canada and the European Free Trade Association (EFTA). The agreement is a strong response to protectionist measures taken by the United States. However, the agreement will falter if the Brazilians and the Argentines are unable to implement the rigorous domestic reforms which in-turn could bring a protectionist government at the helm of Mercosur. It was Mercosur in 1991 that generated strong and strategic ties between Argentina and Brazil and 2020 again calls the neighbors to link up in hope to regain and rebuild their economies and bring stability in the region.

\section{REFERENCES}

Al Jazeera. (2019, August 23). Ireland, France set to block EU-Mercosur trade deal over Amazon. Retrieved from Al Jazeera: https://www.aljazeera.com/ajimpact/ireland-blockeu-mercosur-trade-deal-amazon-fires-190823095908509.html

Arana, A. G. (2017). Analytical framework: relations between the European Union and Mercosur. In A. G. Arana, The European Union's Policy Towards Mercosur. Manchester University Press.

Arana, A. G. (2017). Non-institutionalized relations between the EU and Mercosur. In A. G. Arana, The European Union's Policy Towards Mercosur. Manchester University Press. 
International Journal of Social Science and Economic Research

ISSN: 2455-8834

Volume: 05, Issue: 04 "April 2020"

Arana, A. G. (2017). The most productive years of EU-Mercosur relations. In A. G. Arana, The European Union's Policy Towards Mercosur. Manchester University Press.

Bajo, C. S. (1999). The European Union and Mercosur: A Case of Inter-Regionalism. Third World Quarterly, 927-941.

Bulmer-Thomas, V. (2000). The European Union and MERCOSUR: Prospects for a Free Trade Agreement. Journal of Interamerican Studies and World Affairs, 1-22.

Claire Felter, D. R. (2019, July 10). Mercosur: South America's Fractious Trade Bloc. Retrieved from Council on Foreign Relations: https://www.cfr.org/backgrounder/mercosur-southamericas-fractious-trade-bloc

Furia, G. (2019, October 6). EU-Mercosur FTA: Threats and Challenges. Retrieved from Global Risk Insights: https://globalriskinsights.com/2019/10/eu-mercosur-trade-agreement/

Michael Baltensperger, U. D. (2019). The European Union - Mercosur Free Trade Agreement: Prospects and Risks. Brugel.

Nguyen, D. B. (2019). A New Examination of the Impacts of Regional Trade Agreements on International. Journal of Economic Integration ,, 236-279.

Pantaleo, L. (2014). Towards an EU-Mercosur Investment Agreement. The EU in International Affairs, 47-64.

Philip Blenkinsop, L. K. (2019, July 28). EU, Mercosur strike trade pact, defying protectionist wave. Retrieved from Reuters: https://www.reuters.com/article/us-eu-trade-mercosur/eumercosur-strike-trade-pact-defying-protectionist-wave-idUSKCN1TT2KD

Taladrid, S. (2019, August 28). Argentina Considers a Return to Peronism. Retrieved from The New Yorker: https://www.newyorker.com/news/news-desk/argentina-considers-a-returnto-peronism 